\title{
Towards sustainable urban water governance in Denmark: collective building of capabilities in local authorities
}

\author{
Nielsen, Susanne Balslev; Jensen, Marina Bergen \\ Published in: \\ International Journal of Innovation and Sustainable Development
}

Publication date:

2016

Document Version

Peer reviewed version

Link back to DTU Orbit

\section{Citation (APA):}

Nielsen, S. B., \& Jensen, M. B. (2016). Towards sustainable urban water governance in Denmark: collective building of capabilities in local authorities. International Journal of Innovation and Sustainable Development, 10(2), 103-119.

\section{General rights}

Copyright and moral rights for the publications made accessible in the public portal are retained by the authors and/or other copyright owners and it is a condition of accessing publications that users recognise and abide by the legal requirements associated with these rights.

- Users may download and print one copy of any publication from the public portal for the purpose of private study or research.

- You may not further distribute the material or use it for any profit-making activity or commercial gain

- You may freely distribute the URL identifying the publication in the public portal

If you believe that this document breaches copyright please contact us providing details, and we will remove access to the work immediately and investigate your claim. 


\title{
Towards sustainable urban water governance in Denmark: Collective building of capabilities in local authorities
}

\author{
Susanne Balslev Nielsen \\ Department of Management Engineering, Building 424, \\ Technical University of Denmark, 2800 Lyngby, Denmark \\ sbni@dtu.dk \\ Marina Bergen Jensen \\ Design and Construction of Urban Landscapes, Rolighedsvej 23, \\ Copenhagen University, 1958 Frederiksberg C, Denmark \\ mbj@ign.ku.dk
}

Susanne Balslev Nielsen is associated professor at DTU Management Engineeringand deputy in Centre For Facilities Management at the Technical University of Denmark. She is specialized in sustainability in the build environment and has written a large number of publications about integrating sustainability in urban development and infrastructure management. Her research addresses the needs of professionals and advances the knowledge about challenges and benefits of integrating the sustainability perspective in context specific engineering. In 2010 she received the award as European FM-researcher of the year. Susanne is educated as Civil Engineer (1993) and received her Ph.D. (1998) for her study of sustainable transformation of urban infrastructure. Professor II in Facilities Management at Oslo and Akershus University Collage of applied sciences since August 2014.

Marina Bergen Jensen is professor of Design and Construction of Urban Landscapes Adapted to Climate Change. She holds key competencies within water quality management by use of green technologies, and within stormwater management by use of the urban landscapes. She has invented the patented water treatment technology Dual Porosity Filtration, and is running three larger national research projects, all dealing with climate change adaptation of existing urban areas by use of the urban landscapes, the total KULIFE budget representing approximately 2 million Euro. She is responsible for a masters course, 'Urban Ecosystems - structures, functions and design", and is currently supervising 6 PhD-students.

\begin{abstract}
To address the climate adaptation of cities, today's water managers need more than technical skills to drive sustainable urban water projects, which also stimulate demand for post-graduate education so that professionalisation of integrated sustainable water management in the public sector can be achieved. The "Urban Water Platform" was tested and is hereby presented as a course concept for building collective capabilities for integrated sustainable water design among local authorities in Denmark. The course is an innovation because (1) it invites urban planners, road and park managers, and sewage managers to take part in a dialogue about sustainable urban water projects, while collectively exploring new design solutions; (2) it facilitates an appreciative communication between several disciplines; and (3) it promotes careful planning in the early stages of an urban water construction project.
\end{abstract}

\section{Keywords}

Denmark; SUD; sustainable urban water design; climate adaptation of cities; building capabilities; local authorities; public sector innovation; stakeholder dialogues; appreciative communication; transdisciplinary approach; sustainability in local authority governance; social learning in the water sector; organisational learning; integrated storm water management; sustainable urban water course. 


\section{THE CALL FOR SUSTAINABLE URBAN WATER DESIGN}

Flooding in urban districts in Denmark as well as in other developed countries has opened people's eyes to climate change and to the type of practical impact it might have (e.g., Backhaus et al. 2012; and Frantini et al. 2012). Professionals are gathering to promote visions of future water technology and infrastructure, and they point to the potential for water technologies to ensure functionality and wellbeing as well as green growth in Europe (European Council 2004), specifically Denmark (ATV 2011). As pre-conditions for their visions, such professionals indicate the need for innovation; visionary and courageous politicians; and water managers with new capabilities. These requirements represent the point of departure for this paper, which also takes into account the ability of public local authorities to qualify ideas about urban water projects (e.g., new urban settlements, enlargement of drainage systems or redevelopment of urban areas) and to ensure that private or public investments in urban water construction projects lead to greater sustainability, environmentally, socially and economically.

Researchers (e.g., Brown 2005; Meene et al. 2011) argue that rethinking water management in terms of more integrated and holistic practice will require a new institutional setting. Nevertheless, much can be achieved if urban managers, water managers and administrators of roads, parks and nature can be united and form a project team in which their existing capabilities are nurtured and harnessed in the right way, which is what the "Urban Water Platform" is all about: enabling multidisciplinary teams to collaborate.

The Urban Water Platform originated from the Danish multidisciplinary 2BG research project (Black, Blue, Green: Integrated infrastructure planning as the key to sustainable urban water systems, 2007-2012). The project explored the possibilities for a paradigm shift in the field of urban water systems, from large pipe drainage solutions to water handling solutions that focus not only on capability and costs but also on citizens' quality of life and the long-term functionality of applied management concepts.

In terms of storm water, the 2BG project identifies the following key challenges to analyse:

1. The potential for massive infiltration to avoid sewer overflow and recharge local streams and aquifers,

2. Methods for water quality control to avoid pollution from receiving environments and improve storm water harvesting opportunities, and

3. Options for including technical water systems as assets in urban life.

This paper discusses the Urban Water Platform and the associated course context. Furthermore, the paper provides information on transition management (Senge et al. 2008) within the context of the climate adaptation of cities and actions to facilitate learning and innovation in public organisations. Against this background, the paper suggests a course concept for developing the skills required not only for interdisciplinary thinking but also for transdisciplinary and multifunctional (Fratini 2012) thinking in urban water projects. The paper is based on integrated water management in a Danish context. Nonetheless, the generic management challenges addressed herein also exist in other countries (Castro and Heller 2012, Backhaus et al. 2012), specifically in organisations that want to move from disciplinary thinking to multidisciplinary or transdisciplinary thinking. Therefore, the results of this paper are deemed applicable outside the Danish context.

The remainder of the paper is structured as follows. First, the principles for implementing an integrated urban water project are presented. The urban water platform concept (stakeholders, course structure) is then outlined. Finally, the value of the urban water concept in making local 
authorities able to realise sustainable urban water projects is evaluated and discussed.

\section{BUILDING LOCAL CAPABILITY FOR SUSTAINABLE URBAN WATER}

Sustainability in urban water systems refers to (1) a sound management of freshwater as an essential resource, i.e., the restoration of the natural water balance around towns and cities and the improvement of water quality, and (2) the beneficial use of the water to strengthen the sustainability of urban areas in other respects, for instance, those related to social, educational or recreational values. The potential of the urban landscape to contribute to storm water management by means of storage, infiltration, and evaporation is based on the laws of natural science, whereas the specific design suggested here aims at adding extra value by supporting overall urban development goals related to urban biodiversity, accessibility, safety, economic growth, etc. (Jensen 2008).

Creating a storm water basin to retain storm water promotes biological diversity and citizens' access to the variety provided by nature, but it is also relatively straightforward as a project at the following levels:

- At a strategic level: A local authority owns a location and is willing to invest in local management of storm water and sustainable urban quality;

- At a tactical level: Sustainable storm water design is required in local plans for a location;

- At operational level: Physical and geological conditions make it possible to construct a facility large enough to handle all storm water on-site, and relatively few people will have access to the water or will be familiar with this water.

Nevertheless, there may be disputes about the risk of drowning; the risk of damage due to overflow in extreme situations; the allocation of costs and benefits; aesthetic aspects; and, most importantly, conflicts with other political goals and priorities. However, in most cases, these prerequisites are not in place (Backhaus et al. 2012), and there are multiple socio-technical barriers (Mayntz and Hughes 1988) to current water management.

The need to build new governance capabilities, which is the focus of this article, is highlighted by literature concerning the challenges confronting the successful implementation of decentralised water solutions. Moglia et al. (2010) suggest a framework for assessing risks in formulating decentralised water solutions. They use narratives from water professionals to elicit the tacit knowledge of decentralised water systems experts, with the aim of understanding factors that can influence process failure and help identify failure modes. To promote the realisation of decentralised solutions, the authors conclude that "failure in the political stage has the greatest correlation with the overall difficulty in a development - with institutional inertia and adaptive governance having the greatest influence on the ability to provide efficient policy". Nonetheless, how practitioners such as public servants should address the political level appears to be underexplored.

Local governance regimes also affect the likeliness of the successful implementation of sustainable water management practices. Van de Meene, Brown and Farrelly (2011) characterise three ideal institutional regimes for sustainable urban water governance approaches, based on governance literature and research of tacit knowledge among practitioners: (1) hierarchical governance, (2) market governance and (3) network governance. The authors suggest that "governance scholarship has underutilised tacit knowledge from practitioners, and as a result has not explored the application of the three ideal governance modes, which are often combined in practice, and that this is possibly desirable".

Governance experiments that enable societal learning are considered to be of high importance for 
the transition management of socio-technical systems, such as urban water systems (Bos and Brown 2012). Through a structured case analysis of a 10-year dedicated process in a catchment area in Sydney, Australia, Bos and Brown identify key factors enabling different phases of governance experimentation: (1) champions, (2) networks, (3) space, (4) science/research, (5) reputation and (6) presence of bridging organisations. They conclude that the design of experimentation should explicitly focus on social processes that facilitate the development of innovation networks around the societal problem in question. Focus on societal processes does not exclude technical experimentation; it does, however, offer the potential to explore alternative solutions, appropriate to the context considered. In addition, this focus widens the range of options available for cultural change, alongside structural reforms, to create more sustainable practices.

What is still missing is insight into the communication and collaboration between public servants with different disciplinary backgrounds and into methods for changing current practices. Nielsen et al. (2009) argue that it takes more than technical skills to mobilise the courage to implement sustainable urban design solutions; it takes also practitioners' capability to develop socio-technical networks and storylines to integrate sustainability in design and building processes. Similarly, implementation of sustainable design solutions takes more than courage; it requires capabilities to catalyse network changes. For similar reasons, Cundill and Rodela (2012) argue that, to practice natural resource management in a different way, it is necessary to organise deliberate interactions among multiple stakeholders. The outcome of processes supporting societal learning is improved decision making underpinned by (1) a growing awareness of human-environment interactions, (2) better relationships and (3) improved problem-solving capacities for the participants.

In line with Honadle and Cooper (1989), Ivey et al. (2004), Agranoff (2007), and de Loë et al. (2011), herein, it is argued that sustainable urban water design solutions represent a paradigm shift relative to conventional water system designs based on centralised technology and expert operation. To implement design that changes the public infrastructure and requires citizens' acceptance or even their practical or financial support, public servants have to be able to communicate and to handle the potentially critical negotiations surrounding these issues. Although it is important to be aware of the many different interests that may exist, involving a broader group of stakeholders may affect urban water design and the corresponding realisation process. Herein, it is argued that public servants need the skills to show empathy towards other personal or professional values to be able to facilitate and contribute to constructive dialogue and to argue legitimacy for their engagement in decision making beyond their own operational tasks. The societal process of professionalising multidisciplinary working areas is not addressed further in this paper, but theoretical thinking regarding this topic is offered (Fournier 1999; Galamba 2012), which can be further used to address the working conditions of water management professionals in local authorities or utilities. This paper focuses on the need for building professional capabilities in public organisations to implement sustainable urban water design and suggests that the relevant departments need (1) a better method for collaborating and (2) a shared understanding of the needs of different departmental disciplines that are not their own by education.

\section{METHODOLOGY}

The general research method employed in this study is an action research process that took place over the period 2007-2012 and emphasises the reflections that led local authorities in their transition towards sustainable urban design in strategies and projects.

As is typical for a research project, a plan for disseminating results was considered from the beginning, but at the same time, engagement with practitioners and real-life cases were sought. This effort fostered the idea of developing a learning platform as an action research process, through 
which researchers could learn about what practitioners' were thinking and discuss current theoretical knowledge. At the same time, the practitioners appreciated the interaction with the researchers as resources for the development of their own projects, as well as the prestige associated with being involved with universities.

Throughout the 2BG project there was an on-going dialogue between researchers and practitioners to enable a co-creation of knowledge about integrated urban water systems. In addition, it was discussed how, if desired, the project planning process could be improved, and what skills would be required for the organisation to be able to conceive, design, implement and operate urban water projects with a higher sustainability profile. The 2BG project also included dedicated Ph.D. projects that aimed at creating in-depth knowledge about special technical aspects of sustainable urban water design. However, this article reports only the action research associated with the learning platform.

The interaction between researchers and the course participants to co-generate knowledge about current management practices and to identify any lack of capabilities or management innovations, places the overall research methodology in the action research tradition (Reason and BradburyHuang 2006). The focus of our study was the collective group of urban planners, water managers and road/park managers, which were identified as the core multidisciplinary group for developing capabilities required for sustainable integrated water design. To understand the work practices of the course participants, narratives were gathered, as in social science research. The narratives were either public servants' personal narratives about, e.g., challenges in a work situations, or constructed narratives, aiming at communicating visions to be generally understood by non-expert stakeholders as well.

A qualitative research methodology was used to explore the learning process. This methodology involved the following:

- More than 75 hours of observations and dialogue with participants at 2BG seminars and similar professional gatherings. Group work and informal interviews were documented and reported in an internal work report.

- Documentation of each participant's personal outcome and evaluation of the course through a questionnaire survey at the end of the course.

In the research project, the 6 researchers and representatives from the urban planning association and a water/sewage association worked with 10 local authorities to develop and test the learning platform. All local authorities involved sent groups of 3-5 people, who constituted the local teams and included at least 1 urban planner, 1 water manager, and 1 road and park manager. Thus, it is argued that reasonably detailed insight into the possibilities of and barriers to sustainable urban water design among local authorities, sufficient to provide a proof of concept, was gained. The first test of the Urban Water Platform course included participants from Copenhagen, Odense, Aarhus and Greve, all of which are leading the way in opening drainage systems and climate adaptation. In the second test, 6 other local authorities participated, also with a team from different departments. Because most of the participants were middle-sized to large local authorities (from 50,000 to 540,000 inhabitants), we gained most insight into the present situation from the larger organisations. Many of the smaller local authorities were not able to meet the organisers' requirement to register representatives from 3 different departments to be admitted to the Urban Water Platform course. However, the professional challenges of managing socio-technical transitions should be the same among smaller public authorities.

For the development of the course concept, partnerships were formed with the Danish Town Planning Institute and the Danish Water and Waste Water Association DANVA to align urban 
water learning goals with current capabilities and the Danish local authority context and to validate the observations and conclusions about work life as Danish urban water professional. Both organisations are professional providers of post-graduate courses, which provided a great advantage in terms of course development, announcements of the course and practical logistics. After the first 2 tests, The Danish Town Planning Institute and DANVA continued the course as an ordinary course in their course portfolio and featured researchers as external speakers. Overall, 110 participants from 25 of the total 98 local authorities in Denmark participated in the course.

The findings from the testing of the course concept were validated by a survey conducted in December 2014. The participants from all four classes were once again asked to share their views on the effect of their participation, this time retrospectively (3 to 6 years later). We sent an e-mail with a link to the survey to 99 of the 110 participants; 20 valid replies were received, yielding a response rate of approximately $20 \%$, which is quite good taking in consideration the timespan and the fact that the respondents did not gain anything by participating.

\section{THE TRANSITION CHALLENGES}

In the literature and through observations, a broader group of stakeholders with experience in having a role in the development and implementation of a sustainable urban water project was identified. This group included stakeholders with influence in various stages of the lifetime of an urban water project: the idea, the design, the authorisation, the construction process and its use, operation and maintenance. This broad group of stakeholders is illustrated as a network of actors in Figure 1. Fratini et al. (2012) have similarly identified stakeholders, i.e., water professionals, urban planners, natural scientists/biologists, insurance companies and the general public. However, judging by the practical experience of the course participants, additional stakeholders can either promote or hinder new urban water design, e.g., health authorities that guard against health risks and want prevention initiatives or technology providers who advocate certain technological products and service systems. In our study, we identified the stakeholders (human as well as nonhuman) previously mentioned and their role in a specific working situation. However, we did not study their intermediary role in greater detail as, e.g., in Moss et al. (2009). 


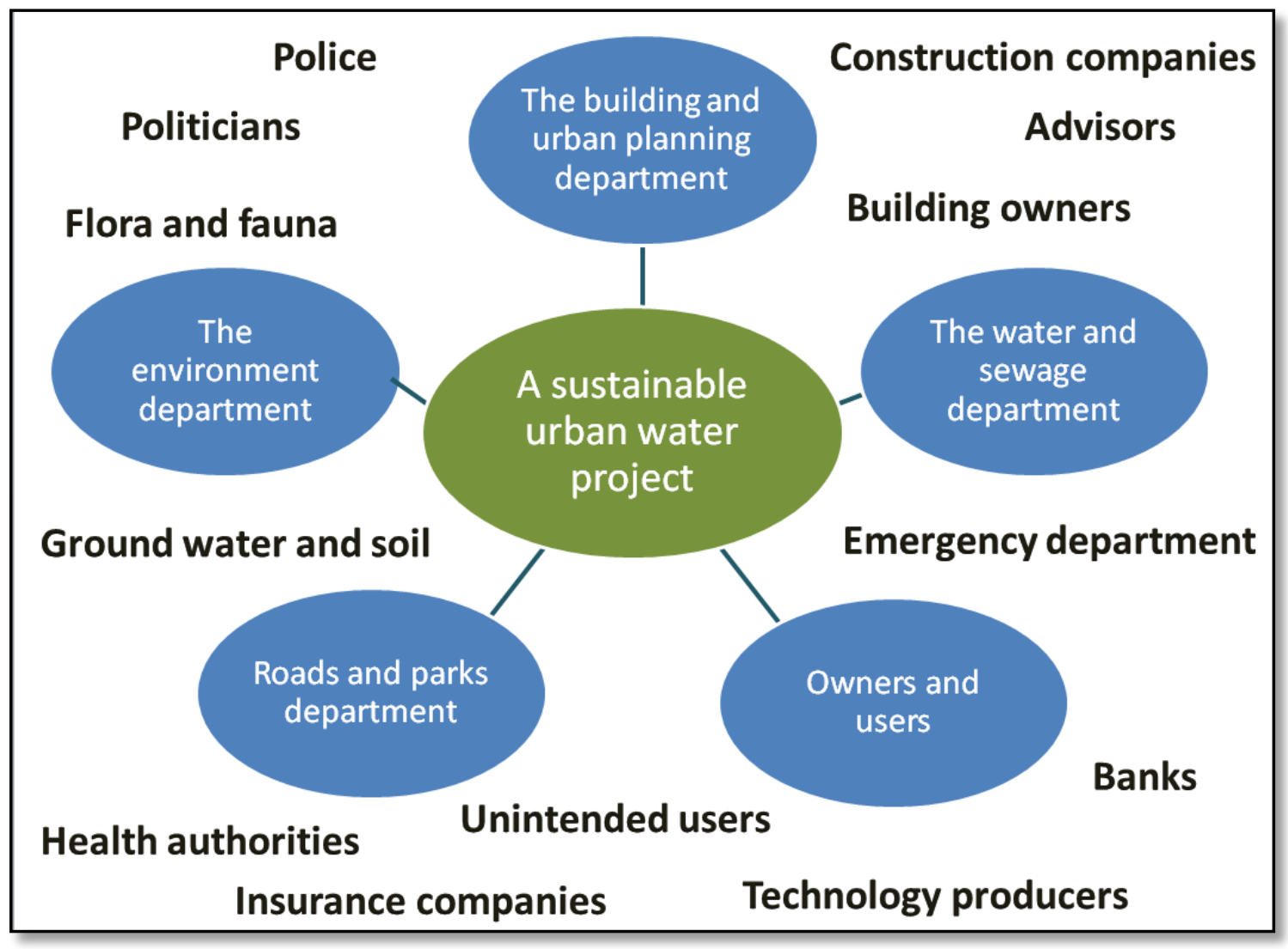

Figure 1: Experienced stakeholders (human and non-human) in sustainable urban water projects.

We argue that there is a need for the development of professional capabilities in water management in accordance with the values of integration, transition and sustainability. The management steering paradigms in use should not be solely bureaucratic, prescribing procedures and relations, but should also form a relational paradigm to lead design negotiations in a socio-technical system with many stakeholders, as in Galamba (2012).

At a personal as well as collective level, it is challenging to try new approaches, move into unknown territory, and break out of conventional practices. Some people like it; others find it difficult and feel vulnerable. For sure, the effort is often more time-consuming in the short term. As one of the participants put it: "Sometimes I think - this is the opportunity to do things differently and in a more integrated way, but then I get overwhelmed and do not know where to start, and then I end up doing things the easiest way I know". Our idea was to facilitate a collective learning process in a neutral learning environment where key stakeholders could test and develop ideas on how to manage innovation in sustainable urban water projects, away from everyday work life and power structures. As facilitators of this innovative and collective learning process, we viewed our aim as "disconnecting the autopilots" in established work practices, where professionals work primary in silos and not in joint processes (Nielsen et al. 2011).

\section{Improving the local phases of the local planning process}

Urban planning and storm water management currently take place in completely separate stages, which leaves the co-design of physical systems with poor chances of success. Our idea is to create an innovation platform, a concept borrowed from innovation system theory (e.g., Tukker et al. 2008), by forming a team of people with complementary capabilities, who are linked to each other through a common responsibility as local authorities and who are capable of communicating and considering the multitude of interests of the broader stakeholder group. We suggest various 
improvements in the early phases of a project design, as illustrated in Figure 2 for the case of improving the local planning process.

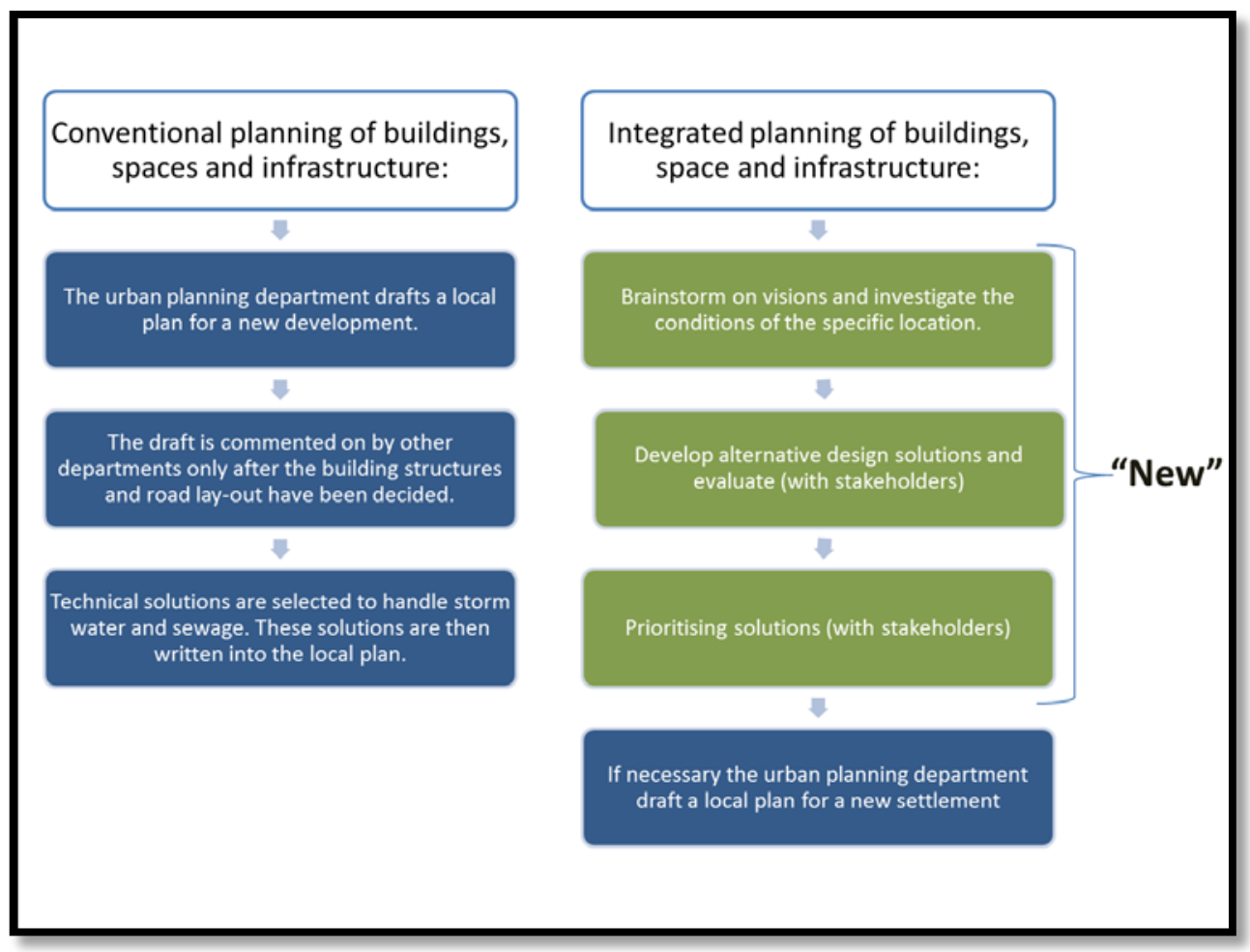

Figure 2: Phases in conventional planning of buildings, spaces and infrastructure in contrast to the suggested integrated approach.

In a conventional design process for buildings, public spaces and infrastructure, the urban planning department is in charge of designing the building structure without technical consideration for water management. In contrast, an integrated design process calls for integrating water management in the building structure, the roof design, the design of surfaces, etc., from the beginning, as illustrated in Figure 2. In the case of existing urban areas, the conventional response to storm water management problems is to enlarge the sewer system, whereas in an integrated approach the urban landscape is re-designed by introducing elements for water storage, infiltration, evaporation and cleansing, the form of which is linked to overall urban development goals.

Three types of learning processes (inspired by Sabatier 1993) are relevant to structuring the type of learning that needs to take place if we are to develop collective capabilities to innovate urban water management.

- $\quad$ Social learning: This is the learning associated with changed common values, norms, goals and perspectives.

- Conceptual learning or problem-oriented learning: This refers to a changed understanding or approach to a problem and its character. It is normally associated with the adoption of new concepts, principles and visions.

- Instrumental learning: This is learning about how various political instruments can be improved to reach given goals. 
Theories of lean management and construction (e.g., Jørgensen 2006) provide useful tools for addressing instrumental learning and issues associated with improving production processes. To some extent, these theories are also useful with respect to water management, in cases in which the organisation must ask the question: "Are our actions based on the right concept and in alignment with values of sustainability?” In Denmark, however, there is also a need for (1) conceptual learning about integrated water management, as in the Urban Water Platform concept, and (2) social learning to promote the values of local handling of storm water and new urban designs. At the instrumental level, there is also a need to develop capabilities among local authorities. For this purpose, we developed the Urban Water Platform concept to build collective capabilities through social, conceptual and instrumental learning.

\section{THE URBAN WATER PLATFORM CONCEPT}

The following section presents the aim, content and process of the Urban Water Platform concept. The aim is to create a network of local authority employees representing the various disciplines relevant to a multi-disciplinary integrated approach to urban water projects. The key participants are the following:

- $\quad$ The roads and parks department;

- The water and sewage department;

- The urban planning department.

We were also aware of the need for support from top management (Elmualim et al. 2010) and, as such, the need to invite key stakeholders from the local political and administrative organisational context.

The aim is also to create a local and national network for knowledge sharing, which is why the course concept stimulates both multidisciplinary teams working in local authorities and disciplinary teams working with participants from across the country.

The activities aim at strengthening each participant's skills not only in dealing with issues that are primarily of a technical character and thus within a natural science discipline but also in dealing with issues of communication, which is more of a management and social science discipline.

The learning process is structured in workshops with homework in between, offering the possibility of gaining deeper insight into the participants’ own professional discipline:

- Urban planners: local planning and urban design;

- Water and sewage planners: sewage planning, new technologies and storm water design;

- Road managers: surface design and capability for storing water;

- Environment and park managers: potentials and reasons for caution from a water quality and biological perspective.

The following provides an impression of the general programme:

Course day 1: Challenges and inspiration

- Overview of the course;

- Towards climate-resistant cities (lecture);

- Working in multidisciplinary teams (lecture);

- Site visit to a model facility (e.g., Augustenborg in Malmoe, Sweden);

- Group work: reflections on input, own motivation and ideas about a local case; 
- Group presentations.

Homework: team work to prepare own project/case: visions, location, ideas, urban design, gather relevant documents and information.

Course days 2 and 3: Ideas, solutions and cases

- Inspiration from national and international cases (lecture);

- Feedback and guidance from experts (researchers and consultants) to each group and their case, based on homework;

- Reflections and next steps in each group;

- Water quality and water quantity (lecture);

- Storytelling (lecture);

- Group work on storytelling (narratives) to communicate the vision of the specific urban water project.

Homework: production of a "postcard" communicating the values and visions of the urban water project.

Course day 4: Anchoring and communication

- The law on planning and the planning hierarchy (lecture);

- The sewage plan as a means of collaborating between the local authority and the utility (lecture);

- An example of a good story about integrated urban water design (storytelling);

- Storytelling from all participating groups;

- Reality check on the realisation of a group strategy from a panel of politicians and an expert in strategy in a local authority context. This activity provides an opportunity to rehearse before an audience before the real test at home.

The programme was adjusted over time based on practical considerations and participant feedback. In the first course, 4 sessions were hosted by the 4 participating municipalities, 1 session at each location. This design was implemented to invest in learning about the specific context in terms of landscape, waterways, the built environment, and the municipality department structure and to determine the most urgent problem areas in terms of urban water design before using the cases in group work. In the following round, when the number of participating municipalities exceeded the number of sessions in the course, this principle came under question. The locations for the course shifted from the premises of participants to professional meeting facilities. This shift was also made to ease the efforts of the organisers and to reduce travel time and distance for the participants.

However, the principle to always find locations affording the possibility for relevant site visits was maintained, as experience with real-life cases is an important didactical principle.

The first course programme included an "after party" for invited local politicians, utilities managers and colleagues of the hosting team, to share the results of the course activities. The after party was meant to support the local team in a dialogue with their superiors and to attract attention to the problem of current water governance and the need for a shift in urban water design and governance practices. In some municipalities, some success was achieved in attracting guests to the after party, which was scheduled as the closing event of the day. Most guests who attended the after party in the municipalities were partners in the 2BG research project, likely because they were already aware of the project and wanted to show their support. Generally, however, very few (3-10) accepted the invitation, and it was agreed that such a low participation rate did not justify the time invested in this event. Later, the after party was converted into an open working lunch, which, unfortunately, 
did not increase the number of accepted invitations. As with the after party, non-participants attributed their choice to lack of time and/or of relevance given their primary tasks and responsibilities. Such responses suggest potential issues in the working culture besides the time/workload ratio, although this issue has not been studied in-depth due to the initial goal and scope of the research.

After receiving feedback on the first course, we reduced the programme from 4 to 3 modules to reduce the time participants spend away from their ordinary tasks. The first module aims at affording societal learning and addresses new values, goals and perspectives. In addition, it stresses the need for a transformation away from the conventional design of buildings, spaces and infrastructure towards climate-resistant cities and integrated design of spaces, buildings and infrastructure, as illustrated in Figure 2. The second module aims at affording conceptual learning, or problem-orientated learning. In the first test of the learning platform concept, the participants worked on the same cases; a nearby location served as a case study for practicing the principles of a new design. Later, we changed the concept and supported the participants in working on their own cases. Thus, several cases were covered during the same course. The third and final module aims at achieving instrumental learning, as general communication and steering tools are practiced to reach the goals of sustainable urban water design in a specific context.

The programme aims at fostering collective capacity building in two ways: (1) through teambuilding within teams from the same local authority and (2) through national networks of urban planners and sewage planners with similar conceptual understandings of sustainable urban water design. During the course, the teaching format changed from a forum for all participants together to group work in homogeneous groups of professionals from either urban planning, water management or roads and parks and/or in multidisciplinary teams from each local authority.

\section{EVALUATION OF THE URBAN WATER PLATFORM CONCEPT}

Participants and organisers evaluated each occurrence of the course on the last day. The final evaluations of the course, which are useful for sharing the lessons learned from this research project, can be summarised as follows.

In general, the participants find the course

- Relevant, entertaining and stimulating;

- Good because it (1) allows for work on own cases and (2) provides feedback from experts and peer reviewers;

- Good because of the site visit, which offers the opportunity to explore "a good example";

- Good because it has led to (1) better relations among colleagues and (2) better mutual understanding, despite different fields of expertise.

At the personal level, the course was also evaluated very positively:

- As one of the participant underlined: "My professional horizon has been expanded". This sentiment was supported by the majority of participants. For instance, others highlight better cross-department collaboration, focus on own strengths, and greater empathy for other disciplines. In addition, others reported that they have gained experience in performing new tasks and have gained new knowledge, e.g., "Local handling of storm water has become a part of my knowledge" and "we have changed from an understanding of urban water as legally problematic to having the courage to work for integrated design in urban water projects". 
Suggestions for improvements:

- The programme included a mix of technical and non-technical lectures, and in the evaluation, the urban planners sometimes suggested cutting down on the technical presentations, whereas the water managers sometimes suggested reducing the non-technical presentations;

- Minor suggestions for change concerned time, accessibility to experts, and food.

Other insights were formulated on the last course day in the second test: "We have underestimated the communication task that is ahead of us. Politicians and citizens need to be engaged too". A politician on the panel then suggested how to address such issues: "We as politicians like to discuss, and you (the public administration) need to leave something for us to discuss and decide. We know you are cleverer, but give us something to have an impact on". This last point appears to be essential for professionals, who aim at integration, networking and co-design of physical systems.

From the perspective of the organisers, it was observed that the local authority teams often did not know each other when they arrived on the first day of the course, but over the three sessions, they developed a shared language and a way of cooperating with one another that demonstrated a mutual understanding of each other's interests and skills. Compared to those received for other courses offered by the co-organisers, DANVA and the Danish Town Planning Laboratory, the course evaluations were among the best they have received.

The idea of sharing knowledge about local projects is based on a problem-based didactic in combination with learning from peers. The experience of running the course several times demonstrated that the participants gained experience, which could help in further innovating public authorities. In fact, during the project period, several suggestions arose regarding how to improve current bureaucratic processes beyond sustainable urban water design. This insight could potentially be investigated in-depth in future research projects.

To document the learning outcomes of the course, a survey was carried out in 2014 to evaluate the course retrospectively and in-depth. A majority of respondents answered that the workshop process had "a significant long-term effect" (70\%; 14 out of 20), whereas a minority answered that the effect was only "short-term" (30\%, 6 out of 20); because their colleagues left or they themselves left, or the participants were assigned other responsibilities. None answered "the course did not have an effect".

The survey confirms that the Urban Water Platform was useful for building collective competences. The most important effects, according to respondents, are presented in Table 1 . As many as $70 \%$ answered that they "became better at integrated and strategic thinking about the build environment and urban water" and "We learned to see your own professional problems in a larger and more multidisciplinary perspective”.

The participants were asked about what didactic element they found most effective: 10 answered "the content in itself", 9 "participation with own team"; 6 "the series of course days over longer period" whereas only 2 answered "the homework". This result indicates that the role of homework should be considered in future versions of the course.

The final part of the survey was an open question inviting the participants to share their personal experience and, e.g., relate their experience in the urban platform course with their experience in other traditional courses and individual education. Eight respondents answered this question. Most respondents provided a positive evaluation of the team participation aspect; specifically, they said that team participation had positive effects in implementing urban water projects as well as in other 
collaborative activities within the local authority. Others highlighted the novelty of the topic and the close link to research as a particular strength. However, two respondents also mentioned that, as in other courses, the organisational capability gained can be at risk when it is easier to carry on business as usual and when colleagues leave for new jobs.

\begin{tabular}{|c|c|c|}
\hline Effects of the urban water platform & \multicolumn{2}{|c|}{$\begin{array}{l}\text { Responde } \\
\text { nts }\end{array}$} \\
\hline $\begin{array}{l}\text { We became better at integrated and strategic thinking about the built environment and urban } \\
\text { water. }\end{array}$ & 14 & $70 \%$ \\
\hline $\begin{array}{l}\text { We learned to view our own professional problems from a larger and more multidisciplinary } \\
\text { perspective. }\end{array}$ & 14 & $70 \%$ \\
\hline I became better at understanding my colleagues, who have different professional backgrounds. & 9 & $45 \%$ \\
\hline We became better at making tacit knowledge explicit. & 7 & $35 \%$ \\
\hline $\begin{array}{l}\text { We gain a new perspective on how we as municipality can contribute to sustainable development } \\
\text { at the societal level. }\end{array}$ & 7 & $35 \%$ \\
\hline $\begin{array}{l}\text { We established the new values for storm water handling that we have today. Storm water should } \\
\text { not only be drained but should be integrated in urban spaces and contribute to recreational } \\
\text { experiences. }\end{array}$ & 5 & $25 \%$ \\
\hline We became better at identifying technical solutions. & 5 & $25 \%$ \\
\hline The effects of the course are visible in our local plans. & 5 & $25 \%$ \\
\hline We became better at communicating with citizens and politicians about technical solutions. & 4 & $20 \%$ \\
\hline The course formed a platform for sharing local and national knowledge. & 3 & $15 \%$ \\
\hline
\end{tabular}

Table 1: The participants of the urban water platform course were asked to choose 1 or more of 11 suggested effects as the most significant learning outcome.

The urban water platform course is viewed as an application of transition theory as it applies the ideas of creating new and collective platforms for societal learning (Senge 2008) by enabling a redefinition of problems and a systemic approach to problem solving. The course concept is developed within the context of sustainable integrated water management but could be applied to other sectors as well, as it draws on general capacity-building tools.

\section{CONCLUSION}

This paper focuses on the need for local authorities to become capable of managing sustainable urban design solutions, an area in which Danish local authorities did not have much experience when the study started in 2007. Through knowledge sharing among the most experienced local authorities, work life challenges were identified and a course concept was developed to facilitate a collective learning process for multidisciplinary teams from local authorities.

This Urban Water Platform concept was tested 4 times, and the results demonstrate that the concept 
can enhance organisational capabilities to provide an integrated approach to sustainable urban water systems. The participants became familiar with a new concept of sustainable urban water systems, relating water issues to other urban development aspects, e.g., social, educational and recreational values.

The course provided participants with opportunities to develop ideas and involved on-paper testing of the concept adapted to a specific location. Participants engaged in these activities in dialogue with peers and experts in integrated urban design and integrated water management. According to the participants, the course offers opportunities for both conceptual learning and institutional learning, as they learned both how to design and how to communicate with various stakeholders. The long-term effects of the course were documented by conducting a survey, the results of which indicate that the national knowledge sharing network was temporary, but there is a long-term effect with respect to the capability for integrated thinking in multidisciplinary teams.

Through multidisciplinary teams and a facilitated process, the course succeeded in "disconnecting the autopilot" in the participating teams' thought processes and introducing an innovation platform for achieving sustainability at the strategic, tactical and operational levels.

\section{REFERENCES}

- Akademiet for de Tekniske Videnskaber (2011) Fra vandteknologi til grøn vcekst: Visionsrapport. ATV Lyngby, Denmark. http://www.atv.dk/category/12-rapporter.

- Backhaus, A., Dam, T. and Jensen, M.B (2012): Stormwater management challenges as revealed through a design experiment with professional landscape architects. Urban Water Journal, Vol. 9, No 1. Taylor and Francis.

- Bos, J. J. and Brown, R. R. (2012) Governance experimentation and factors of success in socio-technical transitions in the urban water sector. Technological Forecasting and Social Change Vol. 79, No 7, pp. 1340-1353;

- Brown, R. (2005) Impediments to Integrated Urban Stormwater Management: The Need for Institutional Reform. Environmental Management, Vol. 36, No. 3, pp. 455-468.

- Castro, J.E. and Heller, L. (Eds.) (2012) Water and Sanitation Services: Public Policy and Management, Earthscan. ISBN: 978-0-415-50703-5.

- Cundhill, G. and Rodela R. (2012) A review of assertions about the processes and outcomes of social learning in natural resource management. Journal of Environmental Management, Vol. 113, pp. 7-14.

- Elmualim, A., Shockley, D., Valle, R., Ludlow, G., Shah, S. (2010). Barriers and commitment of facilities management profession to the sustainability agenda. Building and Environment, Vol.45, No 1, pp. 58-64.

- European Council (2004): Environmental Technologies Action Plan.

- Farrelly, M. and Brown, R. (2011). Rethinking urban water management: experimentation as a way forward? Global Environmental Change. Vol. 21, No 2, pp. 721-732.

- Fournier, V. (1999) The appeal to 'professionalism' as a disciplinary mechanism. The Sociological Review. Vol. 47, No 2, pp. 280-307.

- Fratini, C.; Geldof, G.D., Kluck, J. and Mikkelsen, P.S. (2012): Three Points Approach (3PA) for urban flood risk management: A tool to support climate change adaptation through transdisciplinarity and multifunctionality. Urban Water Journal, Vol. 9, No. 5, pp. 317-331.

- Galamba, K. (2012) Public Facilities Management and Action Research for Sustainability. PhD Thesis. Department of Management Engineering, Technical University of Denmark.

- Grimshaw, B. (2001). Ethical issues and agendas. Facilities, Vol. 19, Issue 1, pp. 43-51. 
- Honadle, G and Lauren, C. (1989). Beyond coordination and control: An interorganizational approach to structural adjustment, service delivery, and natural resource management. World Development, Vol. 17, No 10, pp. 1531-1541.

- Ivey, J.L.; Smithers, J.; de Loë, R. and Kreutzwiser, R. D. (2004) Community Capacity for Adaptation to Climate-Induced Water Shortages: Linking Institutional Complexity and Local Actors. Environmental Management. Vol. 33, No 1, pp. 36-47.

- Jensen, M.B. (2008). “Stormwater Management in the Urban Landscape”. Paper presented at the 11th International Conference on Urban Drainage. August 31 to September 5, 2008 Edinburgh, Scotland.

- Jørgensen, B. (2006): Integrating Lean Design and Lean Construction: Processes and Methods. PhD Thesis. Technical University of Denmark.

- $\quad$ de Loë, R.C. and Plummer, R. (2010) "Climate change, adaptive capacity and governance for drinking water in Canada”, in Armitage, D. and Plummer, R. (eds.), Adaptive Capacity and Environmental Governance, Springer Series on Environmental Management, pp.157-178.

- Mayntz, R and Hughes, T.P (eds) (1988) The Development of large technical systems. Frankfurt am Main, Campus Verlag.

- Moglia, M., Cook, S., Sharma, A. K. and Burn, S. (2011) Assessing decentralised water solutions: towards a framework for adaptive learning. Water Resources Management Vol. 25, No 1, pp. 217-238.

- Moss, T., Medd, W., Guy, S. and Marvin, S. (2009) Organising Water: The Hidden Role of Intermediary Work. Water Alternatives. Vol. 2, No 1.

- Nielsen, S. B, Hoffmann, B, Quitzau, M-B \& Elle, M (2009) Mobilizing the Courage to Implement Sustainable Design Solutions: Danish Experiences. Architectural Engineering and Design Management, Vol 5, No. 1, pp. 53-61.

- $\quad$ Nielsen, S.B, Jensen, M.B., Øhlenschlæger, N., Jensen, E.H, Andersen, H.K. and Dengsøe, N (2011) 'Disconnecting the autopilot in urban water projects: creating an innovation platform for sustainability'. in Paper presented at The IWA conference: Cities of the Future: sustainable Urban Planning and Water Management, May 2011, Stockholm.

- Reason, P. and Bradbury-Huang H. (Eds.) (2006) Handbook of Action Research: Concise Paperback Edition. SAGE Publications.

- Sabatier, P.A. (1993) "Policy Change over a Decade or More” in Sabatier, P.A. and Jenkins-Smith, H. (Eds.) Policy Change and Learning: An Advocacy Coalition Approach. Boulder,Westview Press.

- Senge, P.M., Smith, B., Kruschwitz, N., Laur, J., and Schley, S. (2008) The Necessary Revolution: How Individuals and Organizations Are Working Together to Create a Sustainable World. The Crown Publishing Group.

- $\quad$ Tukker, A., Charter, M., Vezzoli, C., Strø, E. and Andersen, M.M. (Eds.) (2008) System innovation for sustainability: Perspectives on Radical Changes to Sustainable Consumption and Production. Greenleaf Publishing. 